\title{
Modified comet assay with Giemsa staining: a suitable method for assessing genotoxicity in rats
}

\author{
[Ensaio cometa modificado com coloração de Giemsa: um método adequado \\ para avaliar a genotoxicidade em ratos] \\ M.A.B. Fagiani ${ }^{1,2}$, A. Fluminhan ${ }^{3}$, E. Araújo ${ }^{1}$, L.S.L.S. Reis ${ }^{2} *$ \\ ${ }^{1}$ Alunas de Pós-graduação em Ciência Animal - Universidade do Oeste Paulista - Presidente Prudente, SP \\ ${ }^{2}$ Universidade do Oeste Paulista - Presidente Prudente, SP \\ ${ }^{3}$ Universidade Estadual Paulista - Faculdade de Ciências e Tecnologia - Presidente Prudente, SP
}

\begin{abstract}
The present study tested a comet assay that was modified for compatibility with Giemsa staining to assess the drug genotoxicity in the peripheral blood of rats. We analysed the peripheral blood of 16 female Wistar rats ( $\mathrm{N}=8$ rats/group) from a control group and from a group that was treated with an intraperitoneal injection of $50 \mathrm{mg}$ cyclophosphamide/kg. The comet assay was carried out with modifications of the blood volume and immersion time in the lysing solution and different combinations of electrophoresis conditions (running time, voltage and current), to Giemsa staining. The lysing time and electrophoresis conditions allowed for the expression of all classes of DNA damage during the electrophoresis run, and the comets were efficiently stained with Giemsa. The technique showed high reproducibility for the DNA classes. The results demonstrate that the modified comet assay with Giemsa staining can be standardized for routine laboratory procedures using a $20 \mu \mathrm{L}$ blood sample, $3 \mathrm{~h}$ and $30 \mathrm{~min}$ immersions in the lysing solution and electrophoresis runs with 23 to $25 \mathrm{~V}$ and 310 and $360 \mathrm{~mA}$ of electrical current. The modified comet assay with Giemsa staining that was described in the present study was standardized to be applied in the laboratory routine.
\end{abstract}

Keywords: comet assay, azure stains, mutagenicity tests, genetics, electrophoresis

\section{RESUMO}

O presente estudo testou um ensaio cometa modificado para a coloração de Giemsa para avaliar a genotoxicidade de fármacos no sangue periférico de ratos. Analisou-se o sangue periférico de 16 ratas Wistar ( $n=8$ ratas/grupo) de um grupo controle e de um grupo que foi tratado com uma injeção intraperitoneal de $50 \mathrm{mg} / \mathrm{kg} \mathrm{pv}$. de ciclofosfamida. O ensaio cometa foi realizado com modificações do volume sanguíneo e do tempo de imersão na solução de lise, bem como com diferentes combinações de condições de eletroforese (tempo de corrida, tensão e corrente), para coloração de Giemsa. O tempo de lise e as condições de eletroforese permitiram a expressão de todas as classes de danos no DNA durante a corrida de eletroforese, e os cometas foram eficientemente corados com Giemsa. A técnica mostrou alta reprodutibilidade para as classes de DNA. Os resultados demonstram que o ensaio cometa modificado com coloração de Giemsa foi padronizado para procedimentos laboratoriais de rotina usando-se uma amostra de sangue de $20 \mu \mathrm{L}$, $3 \mathrm{~h} 30 \mathrm{~min}$ de imersão na solução de lise e eletroforese com 23 a $25 \mathrm{~V}$ e $310 \mathrm{e}$ 360mA. O ensaio cometa modificado com coloração de Giemsa descrito foi padronizado para ser aplicado na rotina laboratorial.

Palavras-chave: ensaio cometa, corante azure, testes de mutagenicidade, genética, eletroforese

\section{INTRODUCTION}

The comet assay is frequently used to assess DNA damage to prokaryotic and eukaryotic cells (Møller, 2018), which are caused by genotoxic agents that can be external (chemical and physical) or endogenous (produced by cell metabolism and inflammation) (Gunasekarana $e t$ al., 2015). It can also be used to evaluate DNA damage in carcinogenesis (Møller, 2018) and to

Recebido em 30 de maio de 2019

Aceito em 1 de outubro de 2019

*Autor para correspondência (corresponding author)

E-mail: reis.lsls@gmail.com 
diagnose genetic alterations in animals and humans (Mellado-García et al., 2017).

The comet assay consists of a gel electrophoresis run whereby the electric current is applied to cells embedded in low melt-point agarose to detect DNA strand breaks. The breaks are carried through the electrophoresis run, thereby reproducing the image of comets whose heads and tails correspond to undamaged and damaged DNA, respectively (Moller, 2018).

The slides are traditionally stained with a fluorescent dye to examine and classify the comets that formed. However, slides stained using this procedure must be examined under a fluorescence microscope coupled to a highresolution photomicrographic camera to acquire good comet images, which is a limiting factor, given the high cost of the equipment (Osipov et al., 2014). Another factor that hinders the use of fluorescent dye in the laboratory is that fluorescence intensity decreases rapidly and frequently fades before comets can be counted and classified (Brianezi et al., 2009). In addition, certain fluorescent dyes are toxic and mutagenic, thus requiring the use of personal protective equipment (Brammer et al., 2015).

The Giemsa stain is specific for phosphate groups of DNA and attaches itself to regions containing higher amounts of adenine-thymine bonding in blood and in bone marrow cells. The Giemsa stain, which is used in micronucleus tests (Seager et al., 2014), is a low-cost product that allows for slide reading by optical microscopy (Paliwal et al., 2017).

Cyclophosphamide, which has been used as a positive control in micronucleus tests (Santos et al., 2016), produces different genotoxic and mutagenic effects on DNA, with varying levels of damage. Throughout their cycle, cells appear to be more sensitive to cyclophosphamide in late G1 or $\mathrm{S}$ than in G2, mitosis or early G1. Polynucleotides are more susceptible to alkylation when they are separated during DNA replication, rather than in the coiled arrangement. Cyclophosphamide induces DNA strand breaks by producing extensive crosslinks between and within them (Chabner et al., 1996). As such, the present study aimed to adapt the comet technique so that it is compatible with Giemsa staining in the assessment of cyclophosphamide genotoxicity in the peripheral blood of rats.

\section{MATERIALS AND METHODS}

The experimental protocol was approved by the Animal Ethics Committee (CEUA) of the Universidade do Oeste Paulista, Brazil.

The 16 female Rattus novergicus Wistar rats that were tested weighed $201.2 \pm 16.9 \mathrm{~g}$. They were randomly distributed into 3 experimental groups ( $\mathrm{n}=8$ rats/group) that were maintained under similar environmental conditions, with a $12 / 12 \mathrm{~h}$ light/dark cycle and a temperature of approximately $22 \pm 2{ }^{\circ} \mathrm{C}$. All the groups were fed commercial feed (Supralab ${ }^{\circledR}$, Alisul, Brazil) and received filtered water ad libitum. The control group (Gc) served as a reference for normal blood conditions to confirm that the modified, lysis and buffer solutions for electrophoresis and the combination of time, voltage and/or electrical current were not damaging the DNA. The test group was treated with a dose of $50 \mathrm{mg}$ cyclophosphamide/kg body weight intraperitoneally in rats $\left(G_{\text {cyclo }}\right.$ group) to adjust and standardize the comet assay with the use of the Giemsa stain, according to Villela et al. (2006), which can range from class 0 (undamaged DNA) to class 4 (totally damaged DNA).

After the rats were anaesthetized with $16 \mathrm{mg}$ xylazine $/ \mathrm{kg}$ body weight combined with $60 \mathrm{mg}$ ketamine/kg body weight, blood samples were collected by cardiac puncture in vacuum tubes containing EDTA (Parasuraman et al., 2010). After blood sampling, the rats were euthanasia with sodium thiopental (Thiopentax ${ }^{\circledR}$, Cristália, Brazil) at $100 \mathrm{mg} / \mathrm{kg}$ body weight, as recommended by the National Council for the Control of Animal Experimentation - CONCEA (Brasil..., 2015).

The comet assay on peripheral blood samples from the rats that had been subjected to chemotherapy was modified from the technique described by Silva (2007) to achieve compatibility with the Giemsa staining protocol. The adjustments included changes in blood volume, the sample immersion time in the lysing solution, the electrophoresis conditions (running time, voltage and current) and the Giemsa stain, as described below. A phosphate buffer solution (PBS) (10X) containing $80 \mathrm{~g} \mathrm{NaCl}, 2 \mathrm{~g} \mathrm{KCl}, 21.7 \mathrm{~g}$ $\mathrm{Na}_{2} \mathrm{HPO}_{4} .7 \mathrm{H}_{2} \mathrm{O}$ and $2 \mathrm{~g} \mathrm{KH}_{2} \mathrm{PO}_{4}$ was diluted in $1 \mathrm{~L}$ distilled water. The $\mathrm{pH}$ was adjusted to 7.4 
using $\mathrm{NaOH}$ or $\mathrm{HCl}$, and the solution was refrigerated.

A neutralizing buffer solution $\left(\mathrm{NH}_{2} \mathrm{C}\left(\mathrm{CH}_{2} \mathrm{OH}\right)_{3}\right)$, containing $48.5 \mathrm{~g}$ TRIS, was diluted in $1 \mathrm{~L}$ distilled water. The solution $\mathrm{pH}$ was adjusted to 7.5 using $\mathrm{HCl}$. We mixed $1.5 \%$ agarose gel (containing $1.80 \mathrm{~g}$ of regular agarose) to $120 \mathrm{~mL}$ PBS and heated it in a microwave oven until boiling and complete agarose dissolution. The solution that was produced was directly applied to microscopy slides that had been cleaned previously with a disposable paper towel soaked with $70 \%$ alcohol. which were naturally dried on microscope slide racks. The gel was applied to the slide surface, except for a $1.5 \mathrm{~cm}$ band that remained clean at one of the ends to allow for handling and identification. The slides were stored for 1 to 2 days in a clean, covered container that protected them from moisture to ensure agarose adhesion to the slide and to prevent breakage or detachment during cell lysis or electrophoresis.

We mixed $0.75 \%$ low-melting agarose (containing $1.50 \mathrm{~g}$ low-melting agarose) with $20 \mathrm{~mL}$ PBS and heated the mixture in a microwave oven until boiling to completely dissolve the agarose. The solution was refrigerated in a film-sealed container.

We prepared $178 \mathrm{~mL}$ of lysing solution containing $146.1 \mathrm{~g} \mathrm{NaCl}(2.5 \mathrm{~m}), 37.2 \mathrm{~g}$ EDTA $(100 \mathrm{mM}), 1.2 \mathrm{~g}$ TRIS $(10 \mathrm{mM})$ and $8.0 \mathrm{~g} \mathrm{NaOH}$. To that end, a magnetic stir bar was used to dilute EDTA in distilled water, with the water added gradually in small portions, to the recommended volume of $1 \mathrm{~L}$. As the solution was dissolved, the other components were added, thus producing a clear, transparent solution. The lysing solution was stored in a dark glass bottle at room temperature. At the time of use, $2 \mathrm{~mL}$ Triton X-100 and 20mL 10\% DMSO were added to the solution, which was refrigerated in a lightprotected container wrapped in aluminium foil.

The buffer solution for electrophoresis $(300 \mathrm{mM}$ $\mathrm{NaOH}, 1 \mathrm{mM}$ EDTA, $\mathrm{pH}>13$ ) was composed of solutions A and B. Solution A contained $200 \mathrm{~g}$ $\mathrm{NaOH}$ and $500 \mathrm{~mL}$ distilled water, and solution $\mathrm{B}$ contained $14.89 \mathrm{~g}$ EDTA and $200 \mathrm{~mL}$ of distilled water. Both solutions were stored in a dark glass bottle at room temperature. At the time of use, $1.5 \mathrm{~mL}$ of solution A was mixed with $0.25 \mathrm{~mL}$ of solution B. When a new solution batch was required, the bottle with the previous solution was completely emptied before being replaced, thereby avoiding changes in the electrolyte composition of the buffer solutions, which could have affected the electrophoresis run. The volume of the solution was always topped off to $1 \mathrm{~L}$ with distilled water.

Microscope slides of the blood samples were prepared in duplicate. We boiled $0.75 \%$ of lowmelting agarose in a microwave oven until it achieved liquid consistency. The procedure was carried out in a partially covered recipient to prevent the distilled water from evaporating, which facilitates blood homogenization with $0.75 \%$ agarose and its application on the slide that was previously covered with $1.5 \%$ agarose. Aliquots of $300 \mu \mathrm{L}$ of $0.75 \%$ agarose and $20 \mu \mathrm{L}$ of blood were homogenized in microtubes, and $80 \mu \mathrm{L}$ aliquots of the mixture were placed on $1.5 \%$ agarose-coated slides and covered with 24 $\mathrm{x} 60 \mathrm{~mm}$ cover slips, thereby promoting an even spreading of the sample. The cover slips were previously cleaned with a disposable paper towel that was soaked with $70 \%$ alcohol and was naturally dried on microscope slide racks. After drying, the cover slip was removed, and the slide was immersed in the cooled lysing solution inside a covered container protected from light. The slides remained in the lysing solution under refrigeration for $3 \mathrm{~h}$ and $30 \mathrm{~min}$.

After lysing, the slides were washed with distilled water and immersed for $20 \mathrm{~min}$ in a buffer solution in the electrophoresis chamber (Hoefer, Holliston, MA, USA). A number of electrophoresis runs were carried out to test different combinations of the time, voltage and/or electrical current. The best results were obtained by applying 23 to $25 \mathrm{~V}$ and 310 and $360 \mathrm{~mA}$ electrical current (Life Technologies Model 250 Gibco BRL Electrophoresis Power Supply) for $20 \mathrm{~min}$, with the current controlled by the volume and concentration of the buffer solution.

After the electrophoresis run, the slides were removed from the rack, immersed in a Petri dish with neutralizing buffer solution for $5 \mathrm{~min}$ and washed 3 times in distilled water. The excess neutralizing buffer solution was removed, and the slides were tilted on a paper towel to remove excess liquid before undergoing the Giemsastaining protocol. 
Staining consisted of covering the slides with a thin layer of Giemsa solution (Bioclin ${ }^{\circledR}$, Brazil). After 5min, the slides were washed with distilled water to remove excess stain and were dried at room temperature. The slides were refrigerated on a wet towel in a chamber until reading. We examined 100 comets on each slide, for a total of 200 comets per sample, given that the slides were produced in duplicate. The slides were examined under a trinocular optical microscope (400x magnification, Leica $\left.{ }^{\circledR}\right)$ coupled with a camera $\left(\right.$ Leica $\left.^{\circledR}\right)$ for image capture.

The cells were classified into four classes of DNA damage, which were determined according to the comet head to tail length ratio, as proposed by Villela et al. (2006). The DNA damage classes corresponded to undamaged DNA, with a cell nucleus but no tail in class 0 ; head-tail ratios $\leq 1$ in class 1,1 to 2 in class 2 and $\geq 2$ in class 3 , while DNA exhibiting only the tail and an unidentifiable head (cell nucleus) were in class 4 . Head and tail lengths were measured using CASP $^{\circledR}$ 1.2.2 software (CASPlab, Wroclaw, Poland), as proposed by Końca et al. (2003).

The total DNA damage index (DI) calculation was adapted from Villela et al. (2006). To that end, the number of comets from each class (0 to 4) was multiplied by the number corresponding to the damage class $(0,1,2,3$ or 4$)$, as follows: $\mathrm{DI}=[(0 \times \mathrm{n}$ class 0$)+(1 \times \mathrm{n}$ class 1$)+(2 \times \mathrm{n}$ class 2$)+(3 \times \mathrm{n}$ class 3$)+(4 \times \mathrm{n}$ class 4$)]$. Therefore, the DI ranged from $0(0 \times 200)$ for undamaged DNA to 800 (4 x 200) for completely damaged DNA.

The comet test data (damage classes 0, 1, 2, 3 and 4 ) and DI followed a non-normal distribution according to the Shapiro-Wilk test. As such, the experimental groups within each damage class and the damage classes within each experimental group were compared using the Kruskal-Wallis test, followed by the Dunn test to compare the medians. The significance level was set to 0.05 (Zar, 1999). The results were expressed as the medians, the first and third quartile and the lower and upper values. For the correlation between the readings of slides 1 and 2 of the same rat, Spearman's correlation test. The significance level was set to 0.05 (Zar, 1999).

\section{RESULTS}

Figure 1 shows the photomicrographs of Giemsastained comets, and Table 1 shows the head and tail measurements (using the $\mathrm{CASP}^{\circledR}$ 1.2.2 software), the DNA distribution and the respective DNA damage classes of the examined comets (1, 2 and 3$)$.

Rats from the $G_{\text {cyclo group showed a lower }}$ undamaged DNA count and a higher DI compared to those from the control group (Figure 2A and 1F, respectively; $\mathrm{P}<0.01$ ) and higher class 2 and class 3 DNA counts than those of the control group (Figure 1C and 1D, respectively; $\mathrm{P}<0.01)$.

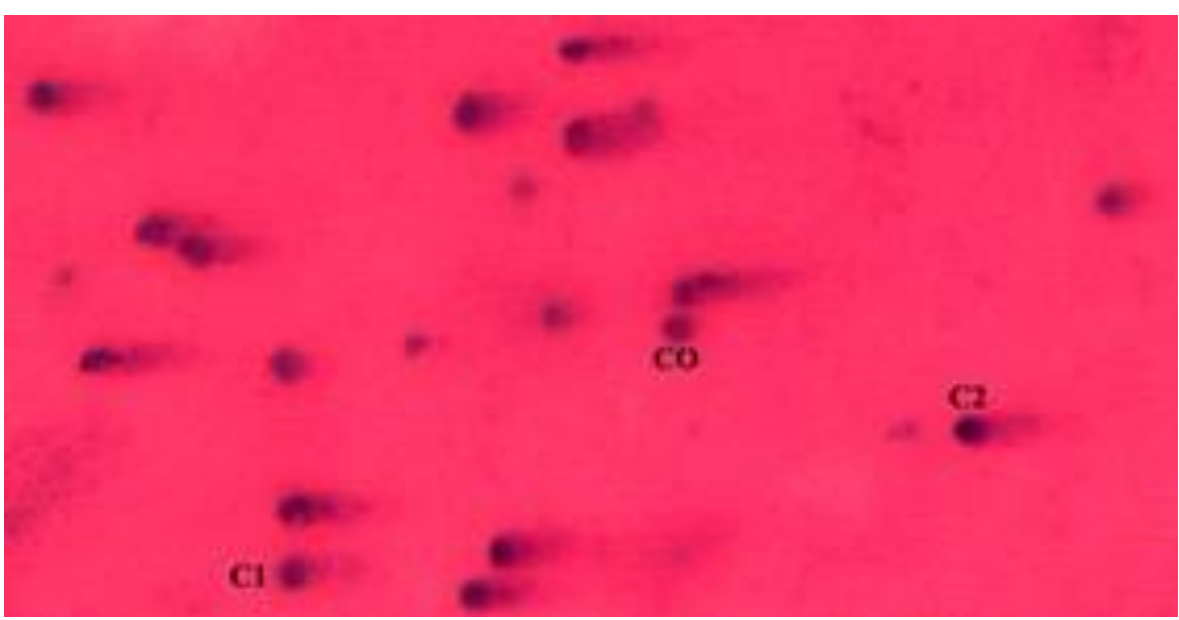

Figure 1. Photomicrographs of Giemsa-stained comets, illustrating: DNA damage classes corresponded to undamaged DNA, with a cell nucleus but no tail in class $0(\mathrm{CO})$; head-tail ratios $\leq 1$ in class $1(\mathrm{C} 1)$ and 1 to 2 in class $2(\mathrm{C} 2)$. 
Table 1. Comet classification into the DNA damage classes, the comet head and tail length, the total length and the DNA distribution into the comet head and tail, as determined by CASP ${ }^{\circledR}$ software

\begin{tabular}{cccccccc}
\hline \multirow{2}{*}{$\begin{array}{c}\text { Comet identification } \\
\text { in Figure 1 }\end{array}$} & $\begin{array}{c}\text { Head to tail } \\
\text { ratio }\end{array}$ & Class & \multicolumn{3}{c}{ Length (pixels) } & \multicolumn{2}{c}{$\begin{array}{c}\text { DNA distribution in the } \\
\text { comet (\%) }\end{array}$} \\
\cline { 4 - 7 } & 0.12 & 0 & Head & Tail & Total & Head & Tail \\
\hline C0 & 0.42 & 1 & 33.0 & 14.0 & 47.0 & 92.4 & 7.6 \\
C1 & 1.49 & 2 & 39.0 & 58.0 & 97.0 & 65.6 & 35.4 \\
\hline
\end{tabular}

DNA damage classes corresponded to undamaged DNA, with a cell nucleus but no tail in class 0 (CO); head-tail ratios $\leq 1$ in class $1(\mathrm{C} 1)$ and 1 to 2 in class $2(\mathrm{C} 2)$.
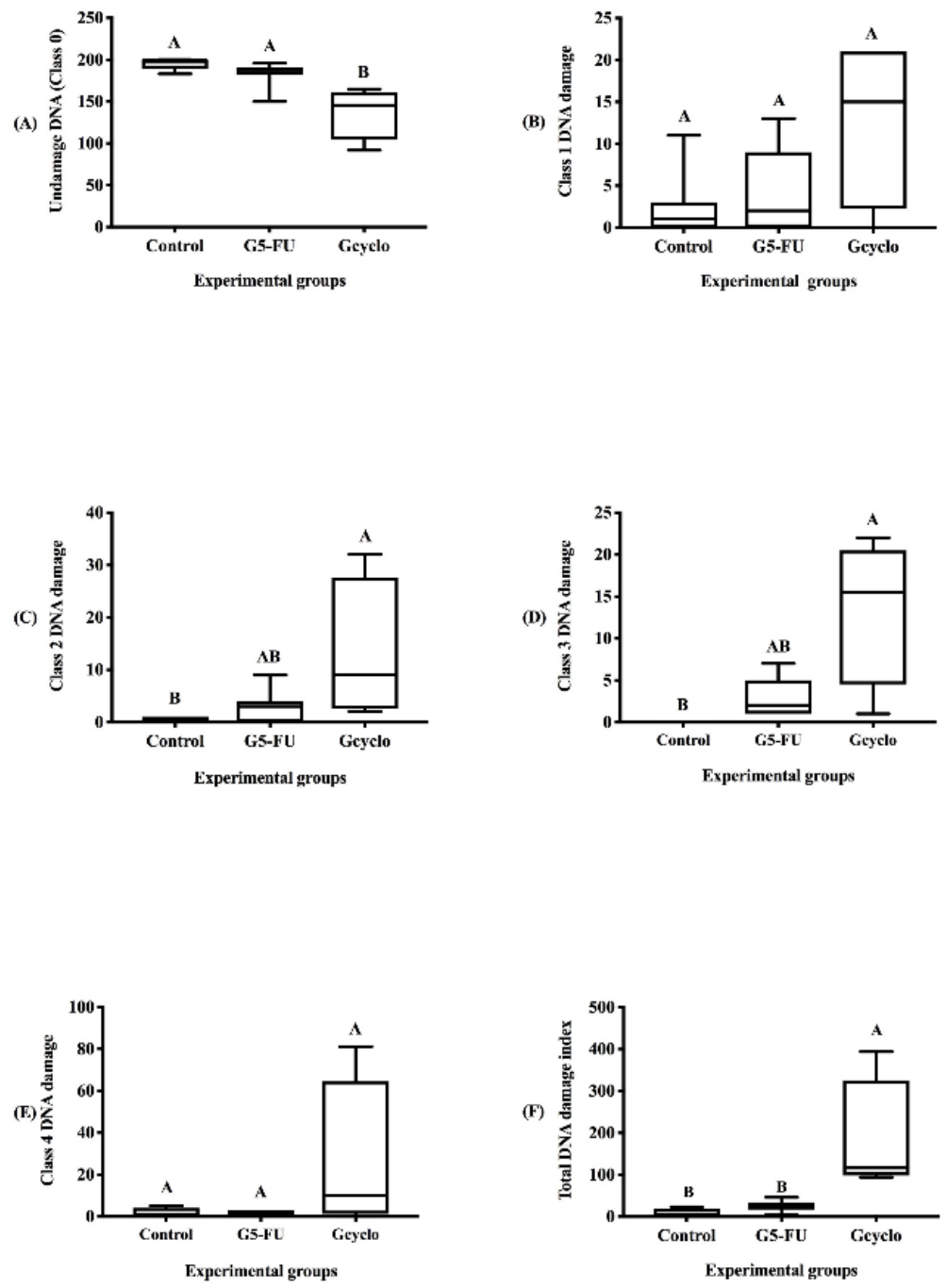

Figure 2. Undamaged (class 0) and damaged DNA (classes 1 to 4) counts and total DNA damage index in Wistar rats after 5-fluorouracil and cyclophosphamide application. DNA damage classes corresponded to undamaged DNA, with a cell nucleus but no tail in class 0 (A); head-tail ratios $\leq 1$ in class 1 (B), 1 to 2 in class 2 (C) and $\geq 2$ in class 3 (D), while DNA exhibiting only the tail and an unidentifiable head (cell nucleus) were in class 4 (E) and total DNA damage index (F). ${ }^{\text {A, B }}$ - Different letters indicate significant differences between the groups for the same DNA damage class $(\mathrm{P}<0.01)$. 
Classes 2 and 3 DNA damage were similar between the $\mathrm{G}_{\text {cyclo }}$ and $\mathrm{Gc}$ groups (Figure. $2 \mathrm{C}$ and $1 \mathrm{D}$, respectively; $\mathrm{P}>0.05)$. The occurrence of classes 1 and 4 damage was similar in the 3 groups (Figure. 2B and 1E, respectively;
$\mathrm{P}>0.05)$. The readings of the two slides (1 and 2) from the same rat sample were highly correlated in the $\mathrm{G}_{\text {cyclo }}$ and $\mathrm{Gc}$ groups for undamaged DNA and for different classes of DNA damage (Table 2).

Table 2. Spearman's coefficient of correlation between the readings of two slides produced from the blood sample from the same rat

\begin{tabular}{llll}
\hline \multirow{2}{*}{ DNA damage class } & $n$ & \multicolumn{2}{l}{ Spearman's coefficient of correlation $\left(r_{s}\right)$} \\
\cline { 2 - 4 } & & Group & $\mathrm{G}_{\text {cyclo }}$ \\
\cline { 2 - 4 } & 7 & $0.68^{*}$ & $0.00^{\mathrm{NS}}$ \\
1 & 7 & $0.98^{* *}$ & $0.98^{* *}$ \\
2 & 7 & $0.66^{*}$ & $0.62^{\mathrm{NS}}$ \\
3 & 7 & $0.24^{\mathrm{NS}}$ & $0.99^{* *}$ \\
4 & 7 & $0.85^{* *}$ & $0.95^{*}$ \\
\hline NS & &
\end{tabular}

NS non-significant $(\mathrm{P}>0.05)$. $* \mathrm{P}<0.05 . * * \mathrm{P}<0.01$.

The DNA damage classes corresponded to undamaged DNA, with a cell nucleus but no tail in class 0; head-tail ratios $\leq 1$ in class 1,1 to 2 in class 2 and $\geq 2$ in class 3 , while DNA exhibiting only the tail and an unidentifiable head (cell nucleus) were in class 4 .

\section{DISCUSSION}

In the present study, the adaptations included changes in the compositions of the lysis solution and the electrophoresis buffer solution, in the electrophoresis settings (running time, voltage and current) and in the Giemsa staining protocol to avoid interferences to the DNA damage and/or to obtain high-quality comet images, with a clear contour of the comet head and tail.

Da Silva (2009) recommended adding $\mathrm{NaOH}$ to the lysis solution until reaching a $\mathrm{pH}$ of 10 to 10.5. In the present study, however, $8.0 \mathrm{~g} \mathrm{NaOH}$ was systematically added to the solution to adjust to the Giemsa staining. If necessary, further $\mathrm{NaOH}$ was added until the solution reached the ideal $\mathrm{pH}$.

To standardize the modified comet assay with Giemsa staining, adjustments in the electrophoresis buffer solution proposed by $\mathrm{Da}$ Silva (2009) were required to maintain the $\mathrm{pH}$, electrophoresis voltage, current and running time. The volumes of solution A and B were adjusted, considering that $\mathrm{pH}$ variation throughout the lysis process and the electrophoresis runs can affect the type of DNA damage that is inflicted. To prevent this, the volume of solution A was reduced to $1.5 \mathrm{~mL}$, and the volume of solution B was reduced to $0.25 \mathrm{~mL}$. Each solution was topped off with distilled water to produce $1 \mathrm{~L}$ solution and to create normal conditions for the electrophoresis run ( 23 to $25 \mathrm{~V}$ voltage and 310 to $360 \mathrm{~mA}$ current) and did not affect the degree of DNA damage during slide staining with Giemsa.

The time to run the gel electrophoresis is, along with adequate voltage and electric current (in milliamps), a key factor in standardizing the protocol adapted to Giemsa staining. A number of combinations of voltage, electric current and running time tested failed to achieve comet formation. However, distinct comets of the different DNA damage classes and treatments were formed by using 23 to $25 \mathrm{~V}$ and 310 to 360mA electric current (BRL life technologies model 250 electrophoresis power supply) for 20min (Figure 2 and Table 1). Similarly, Vieira (2017) obtained the best conditions for comet formation by using nearly $25 \mathrm{~V}$ and $300 \mathrm{~mA}$ current during the run.

Giemsa is a polychromatic stain that allows for efficient localization of the damaged structure and detection of chromosome changes (Brammer et al., 2015). It is part of the Romanowski stain group, which is characterized by a black precipitate that formed with the addition of aqueous solutions of tetramethyl thionine and tetrabromofluorescein (Faria, 2010) and can be observed in the comets that are shown in Figure 1.

The high-quality images that were produced from the peripheral blood samples of rats from the control and $\mathrm{G}_{\text {cyclo }}$ groups, which were treated by the modified comet assay with Giemsa 
staining, allowed for clear visualization of the head and tail of undamaged or damaged comets (Figure 1). Therefore, the comets were reliably classified by optical microscopy into the DNA damage classes (undamaged, 1, 2, 3 and 4), as proposed by Villela et al. (2006) (Figure 1). The method is inexpensive, has easy application and rapid staining. Other benefits of the Giemsa stain concern its low toxicity or mutagenic potential against human health, thereby offering low health risks for lab technicians and has low potential for environmental contamination. Alternatively, alternative fluorescent stains and silver nitrate are hazardous to human health and can cause environmental contamination when inappropriately handled and discharged.

Another great advantage of using Giemsa is that after staining, the slides are viable for reading for 21 days if stored in a moist and refrigerated chamber and, therefore, do not need to be examined immediately after staining. Fluorescent stains require immediate reading after staining because they degrade rapidly when exposed to light, thus making reading progressively difficult (Di-Paolo, 2006).

The high Spearman's coefficients of correlation between the readings of the two slides (1 and 2) that were produced for the same rat (Table 2) shows that the modified comet technique with Giemsa staining also offers good sensitivity and reproducibility to assess the DNA damages that were produced in the rats. Similar results were observed using the comet assay with other stains. The results between the samples can vary as a function of the time when they were collected. However, the assessment of differences by the method is reliable when the sample size is enough (Collins, 2014).

The slides were examined under optical microscopy, and the damage scores were determined as described by Villela et al. (2006). The CASP ${ }^{\circledR}$ 1.2.2 software was used to examine the comets that are shown in Figure 2, providing for damage measures of the head and tail length and the DNA content of each class of DNA (Table 1). This result indicates that the standardization of the modified comet assay with Giemsa stain was achieved; therefore, the inclusion of the method as part of a laboratory routine will produce reliable reports on DNA damage in peripheral blood cells of rats. Accordingly, in a study on DNA damage in human peripheral blood lymphocytes following X-ray exposure, Osipov et al. (2014) reported high reliability $\left(\mathrm{R}^{2}>0.977\right)$ of a comet assay protocol with SybrGreen I or Giemsa stain. They explain that the Romanowsky-Giemsa effect accounts for the high Giemsa sensitivity to the comet assay, thereby providing stability to the comet image and a higher resolution in bright field microscopy than that obtained in fluorescence microscopy.

The low blood volume that is required to run the tests is another important feature of the method that was described in the present study. The test required only 20 microliters of untreated sample, which was immediately homogenized with 300 microliters of low-melting point agarose. The mixture was directly applied on a slide that was pre-coated with regular agarose, which is much more affordable than the low-melting point agarose. On the other hand, the method proposed by Osipov et al. (2014) involves a number of procedures, such as a sample pre-treatment by density gradient centrifugation (Ficollverografin) to separate lymphocytes from other blood components, lymphocyte suspension in PBS to a concentration of $10^{6}$ cell $/ \mathrm{mL}$ and mixture with 600 microliters of low-melting point agarose before 75-microliter aliquots are applied on slides pre-coated with low-melting point agarose9. Therefore, the specific reagents and laboratory devices that are required to run Osipov's method make it more difficult to apply and less affordable than the method studied.

A noteworthy aspect of the described method is that the slides are immersed in Giemsa stain for only $5 \mathrm{~min}$ and then washed only once with distilled water. These procedures are of simple execution and do not require complex laboratory protocols. In contrast, slides prepared by Osipov's method are complex and costly, given that they need fixation in $70 \%$ alcohol for $10 \mathrm{~min}$, Giemsa staining for $30 \mathrm{~min}$ and washing twice for $1 \mathrm{~min}$ with Sorensen phosphate buffer $(\mathrm{pH}$ 6.8) solution.

In the Gc group, $97.4 \%$ of the comets were not damaged (Class 0, Figure 2A), and the total DNA damage index was low (Figure 2F). This result reinforces that the electrophoresis techniques applied (modified lysis and buffer 
solutions, voltage, electric current and running time) and the Giemsa stain did not damage the DNA of the blood cells of the rats.

The control group showed a low occurrence (2.6\%) of DNA damage classes 3 and 4 (Figure 1). Similarly, Hamada et al. (2003) found a low incidence of micronuclei in healthy rats. The DNA can be damaged during cell division, during the processes of denaturation and differentiation, or due to imperfect DNA lesion repair. As such, the damage to DNA was not induced by the modifications of the lysis and electrophoresis buffer solution and/or time, voltage and current during the electrophoresis run.

A low count of undamaged DNA was observed in the $\mathrm{G}_{\text {cyclo }}$ group, probably because the mutagenic effect of cyclophosphamide is higher than that of 5-FU. Moreover, the action mechanism of cyclophosphamide can compromise DNA integrity and function by alkylation, thus explaining the increase in damage classes 2 and 3 and in the total DNA damage index (Figure 1). Because of its high mutagenic potential, cyclophosphamide has been used in other studies as a positive control for the formation of micronuclei (Santos et al., 2016).

\section{CONCLUSIONS}

The modified comet assay with Giemsa staining that was described in the present study was standardized to be applied in the laboratory routine.

\section{ACKNOWLEDGMENTS}

To the University of Western São Paulo (UNOESTE) by providing financial support for the acquisition of materials and equipment.

\section{REFERENCES}

BRAMMER, S.P.; TONIAZZO, C.; POERSCH, L.B. Corantes comumente empregados na citogenética vegetal. Arq. Inst. Biol., v.82, p.1-8, 2015.

BRASIL. Ministério da Ciência, Tecnologia e Inovação. Conselho Nacional de Controle de Experimentação Animal - CONCEA. Diretriz da prática de eutanásia do CONCEA. Brasília, Brasil.
Disponível em: <https://www.mctic.gov.br/ mctic/export/sites/institucional/institucional/concea/ar quivos/legislacao/resolucoes_normativas/ResolucaoNormativa-CONCEA-n-28-de-13.11.2015-D.O.U.-de16.11.2015-Secao-I-Pag.-44.pdf, 2015>. Acessado em: 23 maio, 2017.

BRIANEZI, G.; CAMARGO, J.L.V.; MIOT, H.A. Desenvolvimento e validação de técnica quantitativa da análise de imagem para avaliação do teste do cometa corado pela prata. J. Bras. Patol. Med. Lab., v.45, p.325-334, 2009.

CHABNER, B.A.; ALLEGRA, C. Agentes antineoplásicos. In: HARDMAN, J.G.; LIMBIRD, L.E.; MOLINOFF, P.B. et al. (Eds.). As bases farmacológicas da terapêutica. Atlampa, Colônia: McGraw-Hill Interamericana, 1996. p.909-949.

COLLINS, A.R. Measuring oxidative damage to DNA and its repair with the comet assay. Biochim. Biophys. Acta, v.1840, p.794-800, 2014.

DI-PAOLO, C. Aplicação do ensaio do cometa a estudo de danos ao DNA de robalos, Centropomus parallelus (Poey, 1860), expostos à $\beta$-naftoflavona. 2006. 91f. Dissertação (Mestrado em Ciências) - Instituto Oceanográfico da Universidade de São Paulo, São Paulo, SP.

FARIA, S.R.M. Relatório de estágio. 2010. $184 \mathrm{f}$. Dissertação (Mestrado em Clínicas) - Faculdade de Farmácia, Universidade de Lisboa, Lisboa. POR.

GUNASEKARANA, V.; RAJ, G.V.; CHAND, P. A comprehensive review on clinical applications of comet assay. J. Clin. Diagn. Res., v.9, p.1-5, 2015.

HAMADA, S.; NAKAJIMA, K.; SERIKAWA, T. et al. The effect of aging on the results of the rat micronucleus assay. Mutagenesis, v.18, p.273-275, 2003.

KOŃCA, K.; LANKOFF, A.; BANASIK, A. et al. A cross-platform public domain PC imageanalysis program for the comet assay. Mutat. Res., v.534, p.15-20, 2003.

MELLADO-GARCÍA, P.; MAISANABA, S.; PUERTO, M. et al. In vitro toxicological assessment of an organosulfur compound from allium extract: cytotoxicity, mutagenicity and genotoxicity studies. Food Chem. Toxicol., v.99, p.231-240, 2017. 
MØLLER, P. The comet assay: ready for 30 more years, Mutagenesis, v.33, p.1-7, 2018.

OSIPOV, A.; ARKHANGELSKAYA, E.; VINOKUROV, A. et al. DNA comet Giemsa staining for conventional bright-field microscopy. Int. J. Mol. Sci., v.15, p.6086-6095, 2014.

PALIWAL, V.; JAIN, A.; LAGHAWE, A. et al. Comparision of wet mount examination with giemsa staining and fluorescent staining for detection of Trichomonas vaginalis in clinically suspected cases of vulvovaginitis. Int. J. Curr. Microbiol. Appl. Sci., v.6, p.718-724, 2017.

PARASURAMAN， S.; RAVEENDRAN， R.; KESAVAN, R. Blood sample collection in small laboratory animals. J. Pharmacol. Pharmacother., v.1, p.87-93, 2010.

SANTOS, N.C.; RAMOS, M.E.; RAMOS, A.F. et al. Evaluation of the genotoxicity and cytotoxicity of filling pastes used for pulp therapy on deciduous teeth using the micronucleus test on bone marrow from mice (Mus musculus). Mutagenesis, v.31, p.589-595, 2016.
SEAGER, A.L.; SHAH, U.K.; BRÜSEHAFER, $\mathrm{K}$. et al. Recommendations, evaluation and validation of a semi-automated, fluorescentbased scoring protocol for micronucleus testing in human cells. Mutagenesis, v.29, p.155-164, 2014.

SILVA, J. O uso do ensaio cometa para o ensino de genética toxicológica. SBG - Gen. Escola, v.2, p.30-33, 2007.

VIEIRA, T.Q. O ensaio cometa e a espécie Hypsiboas albopunctatus (Spix, 1824) como ferramentas de avaliação de qualidade ambiental em uma unidade de conservação federal inserida no cerrado goiano. 2017. 63f. Dissertação (Mestrado em Biodiversidade Animal) - Universidade Federal de Goiás, Goiânia, GO.

VILLELA, I.V.; OLIVEIRA, I.M.; SILVA, J. et al. DNA damage and repair in haemolymph cells of golden mussel (Limnoperna fortunei) exposed to environmental contaminants. Mutat. Res., v.605, p.78-86, 2006.

ZAR, J.H. Biostatistical analysis. New Jersey: Prentice Hall, 1999. 663p. 